\title{
Wadden Sea tidal basins and the mediating role of the North Sea in ecological processes: scaling up of management?
}

\author{
Justus E.E. Van Beusekom*, Christian Buschbaum, Karsten Reise \\ Wadden Sea Station Sylt, Alfred-Wegener-Institute for Polar and Marine Research, Hafenstrasse 43, D-25992 List/Sylt, Germany
}

\section{A R T I C L E I N F O}

Article history:

Available online 19 May 2012

\begin{abstract}
A B S T R A C T
The scale of human pressures on marine ecosystems gradually increased from local to global effects during the last centuries. Global warming, sea level rise and trans-oceanic spread of alien species are now or will be major drivers of ecological change in the Wadden Sea. Eutrophication may rank as a superregional effect as the organic matter turnover in the Wadden Sea is driven by import from the North Sea. These effects will not necessarily be uniform across the entire Wadden Sea. A major challenge will be to understand the interactions between global factors with local conditions, both changed by human interference. A conceptual understanding of factors leading to regional differences within the Wadden Sea is only slowly evolving. Based on our understanding of the eutrophication process and a regional comparison of the eutrophication status of the Wadden Sea we propose that wider tidal basins (with a large distance between barrier islands and the mainland) generally have a lower eutrophication status than narrower tidal basins (with a short distance between barrier islands and mainland). This may be explained by a "dilution" of the imported organic matter in wider tidal basins. The interactions between global and super-regional effects on local ecological developments in the Wadden Sea will be complex and pose a major challenge to science, Wadden Sea management and the assessment of ecosystem health as required by EU legislation. The implications of integrating a North Sea view into Wadden Sea management are discussed and we conclude that the river basin approach of the EU Water Framework Directive is not appropriate for the Wadden Sea.
\end{abstract}

(c) 2012 Elsevier Ltd. All rights reserved.

\section{Introduction}

The Wadden Sea is squeezed in between the European mainland and the North Sea. It is geologically speaking a young system formed about 7000 years before present and basically shaped by North Sea and Atlantic hydrodynamic forces accumulating sediments and initiating a series of barrier islands behind which reduced hydrodynamics enabled the deposition of vast sand - and mudflats developing into salt - and freshwater marshes. Most of the sediment that formed the Wadden Sea and adjacent coastal plains is derived from the North Sea and was deposited in the North Sea region during the last ice ages (Beets and van der Spek, 2000; Hoselmann and Streif, 2004).

The Wadden Sea represents the largest tidal flat system in the temperate world stretching along the Dutch, German and Danish

\footnotetext{
* Corresponding author. Present address: Helmholtz-Zentrum Geesthacht, Institute of Coastal Research, Max-Planck-Strasse 1, 21502 Geesthacht, Germany.

E-mail addresses: Justus.van.beusekom@awi.de, Justus.van.beusekom@hzg.de (J.E.E. Van Beusekom).
}

North Sea coast (Reise et al., 2010). Migrating coastal birds use the Wadden Sea to forage and rest on their flyway between Africa and the Arctic. Because of its geological and ecological significance the UNESCO has nominated the Wadden Sea as a world natural heritage site in 2009. The nomination does not only demonstrate the outstanding natural values of global uniqueness but also the willingness of all stakeholders to safeguard the Wadden Sea for generations to come. This dedication has evolved during recent decades from a situation where for instance in the Netherlands plans existed to connect the Wadden Sea barrier islands with dikes to turn the tidal seascape into a polder landscape (e.g. de Jonge, 2009).

While the natural value of the Wadden Sea is now widely acknowledged, it is still used, influenced and modified by human use. In 5-year intervals so-called Quality Status Reports (e.g. Marencic and de Vlas, 2009) summarise the present state of the entire Wadden Sea mainly based on a set of common parameters as described in the Trilateral Monitoring and Assessment Programme (TMAP; Bakker et al., 1998). These assessments compile local data, which are used to highlight regional differences. However, few scientific studies have attempted to explain these regional 
differences. Most focussed on areas where research stations happen to be located (e.g. Philippart et al., 2007; van Beusekom and Reise, 2008; Rullkötter, 2009).

Understanding regional differences is challenging from a scientific point of view and a prerequisite for successful management. The scale of the operational management used to be primarily on a national level based on a trilateral Wadden Sea Plan (CWSS, 1997, 2010), but EU legislation like the Water Framework Directive (European Commission, 2000) or the Marine Strategy Framework Directive (European Commission, 2008) is requiring approaches beyond the three Wadden Sea countries. In the latter cases, baselines or reference conditions have to be defined and as yet a scientific basis is missing to explain the regional differences which would be a prerequisite for a subsequent evaluation of the political consequence.

In this paper we first review the main ecological changes that took place in the regions of the Wadden Sea and then present a conceptual framework to explain observed regional differences and highlight the importance of the North Sea in shaping the ecology of its southeastern fringe, the Wadden Sea.

\section{Long-term ecological change}

The Wadden Sea ecosystem is influenced by many factors both natural and human - acting on different temporal and spatial scales. On geological time scales, Pliocene rivers and Pleistocene ice ages accumulated large sand deposits in the North Sea basin which were subsequently reworked and transported by a rising and turbulent sea. The resulting land- and seascape together with the living resources have been increasingly modified by human presence since the Wadden Sea ecosystem came into existence. Hunting and fishing led to local extinction of larger animals (Lotze et al., 2005). Diking started almost 1000 years ago on a local scale and finally separated the present Wadden Sea from the mainland by a continuous line of dikes diminishing its original size by about $50 \%$ and decreasing the average distance between barrier islands and the mainland and reducing the extent of episodically flooded marshes (Reise, 2005). Coastal squeeze between the rising sea and expanding coastal development (Doody, 2004; Airoldi and Beck, 2007) has increased the local hydrodynamics and contributed to an enhanced loss of fine particles from the Wadden Sea sediments (e.g. Flemming and Nyandwi, 1994; Dellwig et al., 2000).

van Beusekom et al. (2010) compiled ecological changes in the northern Wadden Sea: The earliest investigations on subtidal species communities in the northern Wadden Sea that allow at least a qualitative comparison with the present situation date back to the second half of the 19th century. Möbius $(1877,1893)$ and also Hagmeier and Kändler (1927) in the beginning of the 20th century observed a diverse epibenthos in tidal channels of the northern Wadden Sea. They described dense beds of subtidal eelgrass (Zostera marina) and mussels (Mytilus edulis) and reefs of European oysters (Ostrea edulis) and Sabellaria spinulosa - a colonial and tube-building polychaete. These earliest investigations were repeated by Buhs and Reise (1997) using a similar gear, i.e. a traditional oyster dredge. Buhs and Reise (1997) and Reise and Buhs (1999) concluded that the epibenthic species richness had declined. Important communities like Sabellaria reefs, subtidal eelgrass beds and native oyster beds were diminished. The decrease in species richness was mainly attributed to fisheries. The disappearance of subtidal eelgrass beds is probably related to the so-called wasting disease by the slime mould Labyrinthula sp. that wiped out most of the eelgrass beds during the 1930's (Wohlenberg, 1935).

Earliest studies of the intertidal zone in the North Frisian Wadden Sea allowing a comparison with the recent situation date back to investigations performed by Nienburg (1927) and Wohlenberg (1937) during the 1920's and 1930's. They mainly focussed on the benthic community of the intertidal of Königshafen, a small embayment in the northern part of the island of Sylt (Fig. 1). Reise et al. (2008) repeated Wohlenberg's investigation between 1988 and 2006 and detected significant changes (Fig. 2). In the upper intertidal zone, muddy sediments originally inhabited by the mud shrimp Corophium volutator are now replaced by a sandy berm with the lugworm Arenicola marina. Below, former seagrass beds are now replaced by recurrent dense green algae mats (Enteromorpha spp., Chaetomorpha spp., Ulva sp.). The lowest intertidal zone was dominated by extensive mussel beds and attached macroalgae (Fucus vesiculosus forma mytili) but nowadays these mussel beds are largely gone and replaced by reefs of the introduced Pacific oyster Crassostrea gigas. Reise et al. (2008) suggest that the combination of four factors has led to the observed changes during seven decades: (1) sea level rise being responsible for increased sandiness at the expense of mud inhibiting C. volutator and facilitating A. marina, (2) eutrophication supported the development of massive green algae mats affecting most infauna and seagrass, (3) extreme weather events initiated the loss of mussel beds with attached fucoid algae and (4) introduced exotic species (about nine) have added to the local species richness.

Considering the southern Wadden Sea, conspicuous changes in the Dutch part comprise a loss of bivalves and seagrass. Kraan et al. (2011) compared present macrobenthos distribution with the situation of about 50-60 years ago and suggested that shellfish fishing on Cerastoderma edulis and $M$. edulis has been the major factor of change. The wasting disease of seagrass in the 1930's wiped out the subtidal Z. marina (e.g. den Hartog and Polderman, 1975; de Jonge et al., 1996). Probably the closure of the Afsluitdijk in 1932 and enhanced turbidity played an important role that eelgrass did not return in the subtidal zone (Giesen et al., 1990a,b). In the intertidal Z. marina and Z. noltii survived but after about 1965 both populations declined among others due to eutrophication (e.g. Philippart, 1995; van Katwijk et al., 1997, 1999). At about the same time, intertidal seagrass also declined in the adjacent southern German Wadden Sea (Kastler and Michaelis, 1999).

Riverine nutrient loads increased especially after 1945 (van Bennekom and Wetsteijn, 1990). Eutrophication caused shifts in nutrient ratios, led to a clear Si limitation (Gieskes and van Bennekom, 1973) and had a major impact on the pelagic ecosystem with enhanced blooms of Phaeocystis globosa (a colony forming flagellate with no Si requirements; Lancelot et al., 1987; Cadée and Hegeman, 2002) and an enhanced primary production

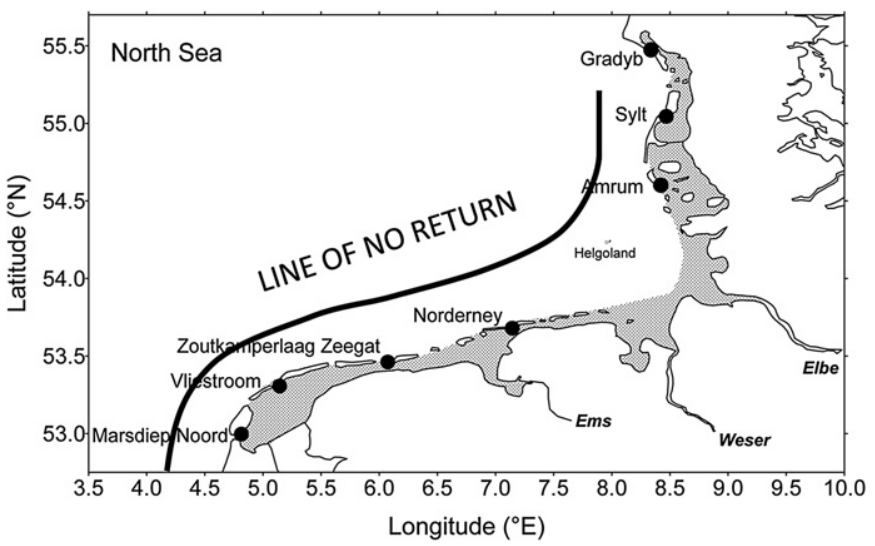

Fig. 1. Map of the Wadden Sea showing the position of time series stations referred to in the text and showing the "line of no return" (after Postma, 1984). 

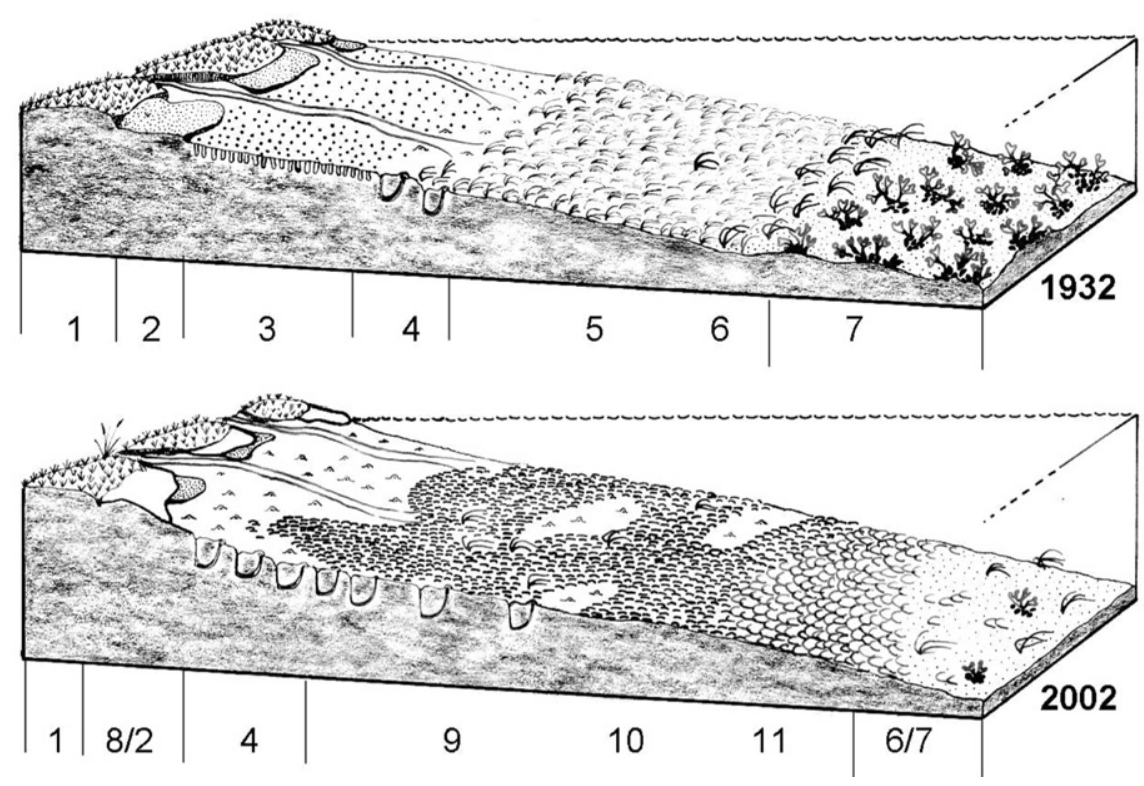

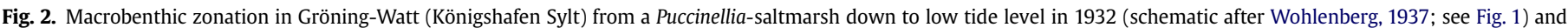

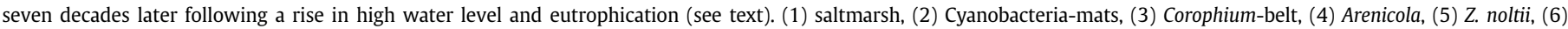

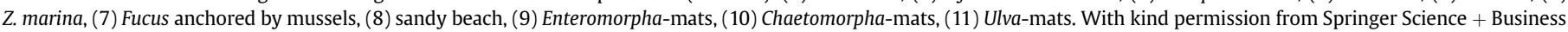
Media: Helgoland Marine Research, Mudflat biota since the 1930s: change beyond return? vol. 62, 2008, 13-22, Karsten Reise, Elisabeth Herre and Manfred Sturm, Fig. 8.

(Cadée and Hegeman, 2002). Eutrophication is considered as one of the most important factors that changed the Wadden Sea ecosystem between the 1950's and 1990's (e.g. de Jonge et al., 1993). Since the mid-1980's nutrient loads into the Wadden Sea and in the major rivers influencing the coastal North Sea are declining and a decrease in summer chlorophyll levels is observed in the entire Wadden Sea (van Beusekom et al., 2009a). Philippart et al. (2007) showed that the decreased nutrient loads had an effect on biota in the western Dutch Wadden Sea. They stressed the importance of phosphorus loads in determining the effect of eutrophication on Wadden Sea species communities. The relative role of silica, nitrogen and phosphorus loads in eutrophication is not clear yet and each element has particular limitation patterns both seasonally and within the Wadden Sea (Loebl et al., 2009).

According to Wolff et al. (2010) and Reise and van Beusekom (2008) the major challenges for future Wadden Sea management and research are sea level rise, increasing global temperature and the introduction of alien species through global trade and aquaculture, and in particular the interactive effects of these global factors which can only be managed on a global scale.

Although these pressures act on a large scale, their effects are not necessarily uniform across the Wadden Sea. For a successful Wadden Sea wide management, it is therefore necessary to understand the regional effect of these large-scale drivers. Despite intensive research activities within the Wadden Sea, little attention has been given to understand the regional differences within the Wadden Sea. This knowledge is a prerequisite for a meaningful evaluation of the assessment data with implications for subsequent management strategies. We exemplify this with eutrophication, a major factor that impacted the entire area Wadden Sea. Since the mid-1980's several monitoring programmes are in place covering the entire Wadden Sea and documenting a general decrease in eutrophication (e.g. van Beusekom et al., 2009a). In this paper we will employ these time series used for the eutrophication assessment to highlight regional differences and to propose a mechanism explaining the observed regional differences.

\section{A tidal basin approach for regional comparisons in the Wadden Sea: driven by suspended matter dynamics?}

Tidal basins and estuaries are the natural subunits of the Wadden Sea and here we use nutrient and phytoplankton data from the QSR 2009 (Marencic and de Vlas, 2009) to suggest a conceptual model explaining observed differences in organic matter dynamics between tidal basins. The basic assumption is that the Wadden Sea is predominantly heterotrophic (e.g. Postma, 1984; van Beusekom et al., 1999), and that the nutrient and organic matter dynamics are mainly driven by organic matter import from the North Sea (e.g. van Beusekom and de Jonge, 2002). In this context it is important to note that organic matter and inorganic matter are intimately entwined (e.g. Postma, 1981) and depending on the scientific focus the inorganic or the organic aspects are highlighted. The concept that organic matter import from the North Sea is essential for the high productivity of the Wadden Sea was first put forward by Verwey (1952) and was further elaborated by Postma (1954), van Straaten and Kuenen (1957) and Postma (1981, 1984).

The first step in the accumulation of SPM (suspended particulate matter and the associated organic matter) is the coastward

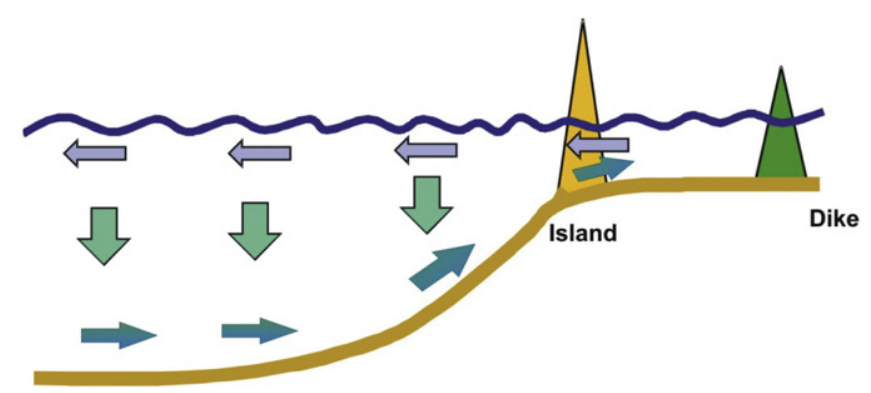

Fig. 3. Conceptual graph showing the density-driven circulation perpendicular to the Wadden Sea and the accumulation of sinking SPM in the bottom layer "pushing" the SPM towards the Wadden Sea. Once within the range of the Wadden Sea "classical" processes like the settling lag and scour-lag (van Straaten and Kuenen, 1957) or tidal straining (Burchard et al., 2008) will effectively keep SPM within the Wadden Sea. 
transport from the North Sea (Fig. 3) towards the Wadden Sea. This is driven by density circulation and is most pronounced during spring and early summer. Wadden Sea water is generally lighter than the adjacent North Sea water due to freshwater discharge. During spring the density differences are enhanced because shallow Wadden Sea water heats up faster than the deeper North Sea and due to peak freshwater discharge during winter and spring. Both factors contribute to a flow of surface water away from the Wadden Sea, which has to be compensated by a bottom return flow. Also during spring and early summer the major phytoplankton blooms occur both in the Wadden Sea and in the North Sea (e.g. Cadée, 1986; Reid et al., 1990). During these blooms flocculation processes (e.g. Alldredge and Gotschalk, 1989) may enhance the settling of organic matter and SPM in the deeper layers thus supporting an efficient transport of freshly primary produced organic matter within the landward bottom current from the North Sea towards the Wadden Sea. This transport of fresh organic matter and SPM can be assumed to be most intense during spring and early summer, in line with enhanced sedimentation during spring and summer (e.g. Cadée, 1980; Andersen et al., 2006). The SPM transport towards the Wadden Sea will fade when autumn cooling starts and denser Wadden Sea water carries SPM away from the coast (Staneva et al., 2009), in line with a decline in sediment accumulation as observed in the List tidal basin (Andersen et al., 2006).

The transport of North Sea SPM towards the coast implies that an SPM minimum should occur at the seaward end of the density circulation zone. Indeed, such a minimum was observed about 50-100 km off the Wadden islands (Postma, 1981). Particles between the SPM minimum zone and the coast have a fair chance to be accumulated in the Wadden Sea, whereas particles beyond the minimum zone have a low chance to be transported towards the Wadden Sea. This imaginary line was coined "the line of no return" by Postma (1984; see Fig. 1). As the distance between the SPM minimum zone and the Wadden Sea is much wider than the Wadden Sea proper, the area from which the Wadden Sea potentially draws its SPM (and containing organic matter) is much larger than the Wadden Sea itself (Postma, 1984). Of course not all organic matter produced between the Wadden Sea and the SPM minimum zone will reach the Wadden Sea directly but may be involved in several cycles of production and remineralisation, enhancing the chance that part of the offshore nutrients will eventually reach the Wadden Sea in the form of organic matter. Given the importance of organic matter import for the organic matter dynamics (production, remineralisation, turnover) and the carrying capacity of the Wadden Sea, one may wonder how large the Wadden Sea in a "broader" sense really is. The picture emerges that the combination of a spring-enhanced coastward bottom current towards the Wadden Sea (mainly due to a faster temperature rise in the Wadden Sea) and a spring bloom enhanced accumulation (enhanced sedimentation) of SPM in the bottom water "pushes" North Sea produced organic matter towards the Wadden Sea (Fig. 3).

Once SPM has reached the Wadden Sea, accumulation processes are responsible that the SPM (and associated organic matter) gradient is maintained (e.g. Postma, 1954; Oost and de Boer, 1994). Burchard et al. (2008) highlighted the importance tidal straining for SPM accumulation especially in the tidal inlets and main tidal channels. Tidal straining refers to increased vertical turbulence during flood when heavier North Sea water moves over less dense Wadden Sea water and reduced vertical turbulence during ebb resulting in a net bottom transport of SPM towards the Wadden Sea. Model exercises by Burchard et al. (2008) demonstrated that tidal straining is an important process keeping up the SPM gradient towards higher concentrations in the inner Wadden Sea.

Especially on tidal flats scour-lag effects (more turbulent energy or current velocity is needed to resuspend a particle than the energy or current velocity at which a particle can settle), settling lag-effects (once the turbulent energy of current velocity allows settling of a particle, it takes some time until it settles while being transported further inland by the flood) are responsible that the SPM gradient is maintained (Postma, 1954; van Straaten and Kuenen, 1957). Oost and de Boer (1994) pointed out that the mean water depth during high tide is smaller (because much of the water is above shallow flats) and thus the chance to reach the sediment is higher than during low tide (because water is confined to deep channels) thus enhancing the coastward transport of SPM with each tidal cycle. In addition, wave attenuation (Ehlers and Kunz, 1993) and biological interactions like filter feeding or microphytobenthic microfilms (Staats et al., 2001; Andersen et al., 2010) will increase the retention efficiency of the Wadden Sea. Thus, the Wadden Sea proper can be regarded as an effective "Keeper" of SPM, at least on a seasonal scale.

Based on the above, two alternative but not exclusive situations can be postulated that may lead to differences in organic matter and SPM accumulation between tidal basins and therefore to differences in the carrying capacity and intensity of biogeochemical cycling within tidal basins: (1) regional differences in organic matter import and (2) local differences in the size of the recipient

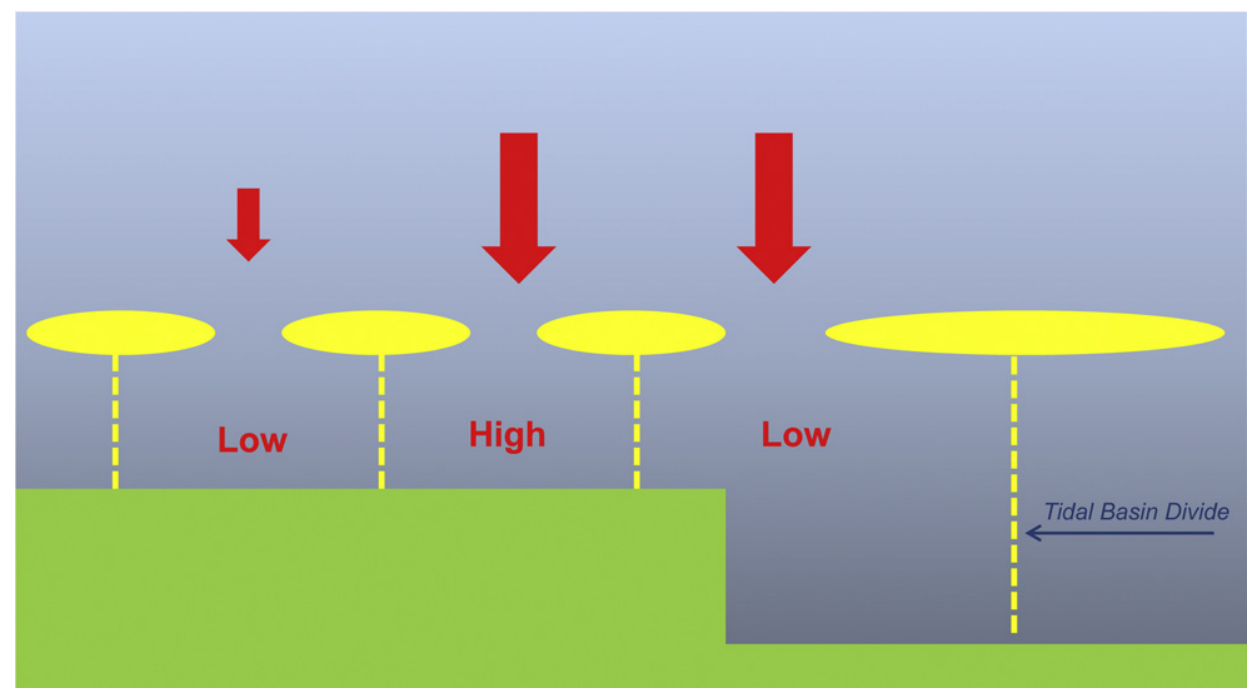

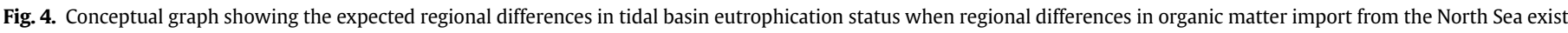

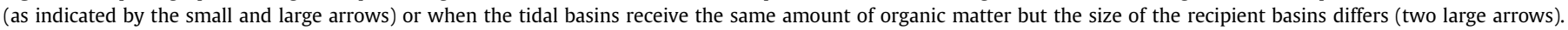


tidal basin (Fig. 4). Several factors may lead to regional differences in organic matter import like (1) regional differences in offshore North Sea primary production, (2) differences in the intensity of the coastward transport of SPM in the bottom layer and (3) the orientation of the coastline relative to currents and winds. If we assume that along a hypothetical Wadden Sea coast the amount of organic matter SPM "pushed" towards the Wadden Sea is similar, then the size of the receiving tidal basin may play an important role in setting the eutrophication status. In narrow basins (short distance between tidal inlet and mainland) the imported organic matter is concentrated in a small area and steep gradients between the North Sea and the shoreline across the tidal basin of e.g. SPM or organic matter degradation products will arise. In wide tidal basins (long distance between tidal inlet and mainland) similar amounts of imported organic matter will be distributed over a larger area and the gradients between the North Sea and the shoreline across the tidal basin will be more gentle.

The regional distribution of the two eutrophication proxies used in the QSR 2009 (van Beusekom et al., 2009a) shows the highest eutrophication status in the narrow tidal basins like in the southern part of the Wadden Sea and lowest in the wider tidal basins like the List tidal basin or the Norderaue (near Amrum). This scenario is in line with the second possibility described above that the size or shape of tidal basins determines the eutrophication status when the import of organic matter from the North Sea to the Wadden Sea is approximately the same along the Wadden Sea coast. In that case the total import is proportional to the length of the coastal stretch against which the North Sea "pushes" SPM and organic matter (compare Fig. 4).

We test the generality of this model by using QSR data. However, in contrast to the strategy applied in the QSR 2009, where regional averages were calculated, we use eutrophication proxies for each of the stations separately. Only those stations are included which lie in the vicinity of the tidal inlets to assure comparability. Tidal basin width was estimated by dividing the tidal basin surface area at high tide by the distance between the tidal divides of adjacent basins. This distance between the tidal divides is assumed to be proportional to the amount of SPM and organic matter "pushed" from the North Sea towards the Wadden Sea.

Eutrophication proxies are related with tidal basin width (Fig. 5). Autumn ammonium values show a significant correlation $(N=8$; $\left.p<0.017 ; r^{2}=0.64\right)$ but the correlation with chlorophyll- $a$ has borderline significance $\left(N=8 ; p<0.017 ; r^{2}=0\right.$.). This is largely due to the higher Chlorophyll- $a$ values in the Dutch time series relative to the best fit. Whether biological or analytical factors are responsible for the observed differences remains to be clarified. In any case, the above analysis suggests that the shape of tidal basins has a pronounced effect on the observed nutrient and Chlorophyll dynamics.

\section{Towards understanding regional differences in the Wadden Sea}

The present Wadden Sea is the product of forces acting from two sides: Land and Sea. Whereas there used to be a clear separation between human-induced impacts from land and natural factors from the sea, this distinction has become blurred. Many of the major threats for the Wadden Sea ecosystem factors identified by Wolff and Binsbergen (1985) were of local to regional character like fishing, hunting or land claim. Most of these factors could be managed and their impact reduced by local authorities and stakeholders over the last three decades. Now the main future challenges identified by Reise and van Beusekom (2008) and Wolff et al. (2010) for ecological Wadden Sea research comprise sea level rise, global warming and introductions of alien species. These factors have
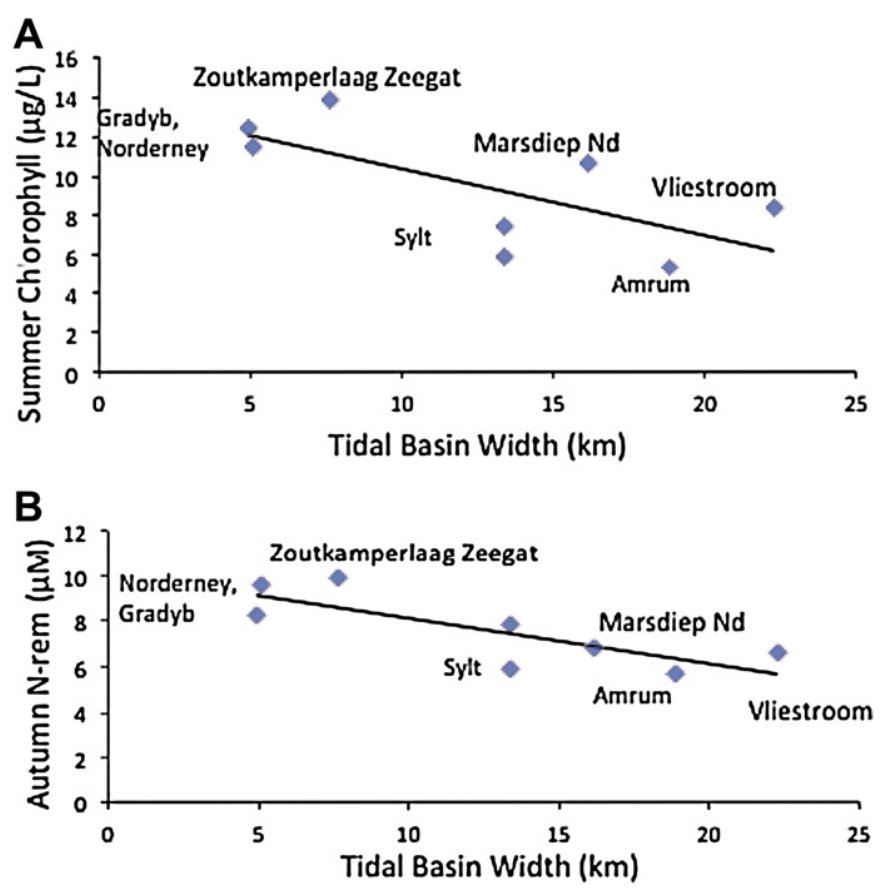

Fig. 5. Plot of eutrophication proxies against the tidal basin width. Tidal basin width is defined as the distance between two tidal basin divides divided by the tidal basin surface. Data cover the years 2000-2006. (A) Summer chlorophyll (average of monthly means; May-September; $N=8 ; r^{2}=0.47 ; p=0.058$ ). (B) Autumn $N$ remineralisation products $\left(\mathrm{NH}_{4}+\mathrm{NO}_{2}\right.$; average of monthly means, September-November, $N=8$; $\left.r^{2}=0.64 ; p<0.02\right)$. The position of the stations is shown in Fig. 1 .

a global character and human impact now has a clear global signature. A main question is whether large-scale effects are uniform throughout the Wadden Sea. Eutrophication data from the Wadden Sea suggest that tidal basins do not respond uniformly and a concept has been presented to explain this. In following we will first discuss the observed differences between tidal basins, extend these views to other parts of the Wadden Sea ecosystem where no long-term data are available and to the influence of North Sea ecosystem processes on the Wadden Sea and finally address the question, whether the Wadden Sea will show a tidal basin-specific response to future changes driven by global temperature rise. We conclude by trying to deduce implications for international Wadden Sea management.

\subsection{Factors influencing differences in organic matter dynamics between tidal basins}

Based on two long-term eutrophication proxies: autumn levels of ammonium and nitrite and summer levels of chlorophyll-a, we identified differences in eutrophication levels between tidal basins. Recently, summer levels of Dissolved Organic Phosphorus (DOP) were suggested as a third eutrophication indicator (van Beusekom and de Jonge, 2012). Although DOP is not a regular part of monitoring programs, available data from the Dutch Wadden Sea and the northern Wadden Sea showed a significant correlation between DOP and the other eutrophication proxies thus confirming the differences in eutrophication status between tidal basins. In particular, lowest values were found in the less eutrophic Wadden Sea near Sylt and the highest in the more eutrophic eastern Dutch Wadden Sea.

As mentioned above, differences in eutrophication between tidal basins can be explained by the width of the basins (defined as tidal basin surface area at high tide divided by the distance between the tidal divides of adjacent basins and approximately equal to the 
distance between islands and mainland). However, other explanations cannot be ruled out. First of all, the position of the stations used is important. As most monitoring stations were near tidal inlets we selected these. This implies, however, that gradients between the mainland and the monitoring stations are not appropriately covered. One possibility is that the gradients are similar in all basins, but that with increasing distance from the mainland nutrient concentrations or phytoplankton levels decrease. This could indeed be the case for nutrients, but for phytoplankton this is not necessarily the case. As turbidity increases towards the mainland phytoplankton growth rates will diminish and we rather expect an opposite gradient with decreasing phytoplankton towards the mainland. The good correlation between the phytoplankton proxy (summer Chlorophyll-a) and the nutrient proxy (autumn levels of ammonium and nitrite) rather indicates a common underlying process which we suggest to be the amount of organic matter (and nutrients) imported from the North Sea.

Differences in exchange rates may also be involved in explaining the observed differences between tidal basins. Among others, exchange rates will depend on the tidal prism and the tidal amplitude. The latter is lowest in the northernmost and westernmost tidal basins and highest in the central part of the Wadden Sea precluding the presence of barrier islands (e.g. Wiersma et al., 2009). High exchange rates will lead to a less pronounced gradient between the North Sea and the tidal basin. Conversely, low exchange rates will lead to the accumulation of nutrients and strong gradients between the North Sea and the Wadden Sea. To our knowledge, no studies have been carried out to estimate and compare exchange rates of differently sized tidal basins. We may expect that smaller basins will have a faster exchange than larger basin. If nutrient fluxes from imported organic material are similar between basins, we expect smaller gradients in the smaller basins. In the Wadden Sea, small basins usually are narrow, while the larger basins are wide (like the List tidal basin in the northern Wadden Sea). This contrasts with our observation that narrow basins have a higher eutrophication status, and with the suggestion of Van Goor et al. (2003) that smaller basins may better trap sediments to compensate accelerating sea level rise than larger basins (see below). In any case, studies are needed to enable a comparison of exchange rates between tidal basins and the North Sea.

The concepts presented here hold for most of the southern Wadden Sea (west of the estuaries of the Weser and Elbe) and northern Wadden (north of the estuaries of the Weser and Elbe) where tidal flats are protected from the North Sea by barrier islands thus forming clearly delineated tidal basin. Near the estuaries of the Weser and Elbe no barrier islands are present due to the high tidal range. Particle exchange in this part of the Wadden Sea is probably dominated by these estuaries, which are both characterised by turbidity maxima. Van Beusekom and Brockmann (1998) analysed the phosphorus dynamics in the Elbe estuary and concluded that a large part of the released phosphate was derived from marine particles. Thus, a significant part of the organic matter imported into the central Wadden Sea is transported further into the estuaries of the Weser and Elbe, remineralised and inorganic nutrients are transported back towards the North Sea. Large freshwater sources like the above mentioned estuaries in the central Wadden Sea or Lake IJssel in the western Dutch Wadden Sea are important landward nutrient sources. Smaller sources like sluices are dwarfed by the amount of nutrients released from imported organic matter (Grunwald et al., 2010).

\subsection{North Sea-Wadden Sea interactions: uniform or tidal basin specific?}

The Wadden Sea ecosystem is strongly determined by its interaction with the North Sea. The import of organic matter is a prerequisite for the high fertility of the Wadden Sea (Verwey, 1952). In the previous section we suggested that North Sea phytoplankton blooms, the formation of aggregates and the coastward transport of these aggregates in a coastward bottom layer towards the Wadden Sea are instrumental in the import process. We further suggested that regional differences in organic matter turnover are best explained by the tidal basin shape: given that the amount of organic matter transported from the North Sea towards the Wadden Sea is similar along the Wadden Sea narrow basins will have a higher concentration of organic matter than wide tidal basins (Fig. 4). Although this assumption is in line with the observed differences (Fig. 5), it is probable that differences in the import of organic matter exist both in space and in time.

Spatial factors include density gradients, depth, exposure to dominant wind directions (the northern Wadden Sea vs. the southern Wadden Sea compare Fig. 1) and primary production levels in the North Sea. Horizontal density gradients (determined by salinity and temperature) have strong seasonal dynamics. For instance depending on weather condition and freshwater discharge, salinity gradients can be steep or weak (e.g. Otto et al., 1990) thus influencing the density circulation. This will have an impact on the import of organic matter into the Wadden Sea. Primary production levels tend to be highest off the North Frisian Wadden Sea (e.g. Joint and Pomroy, 1993). This contrast with the relatively low eutrophication status of the northern Wadden Sea indicating that the ultimate amount of organic matter imported into the Wadden Sea is an intricate interplay of primary production levels and hydrodynamic conditions. We suggest that the combined analysis of remote sensing data and hydrodynamic model output are needed to constrain regional and temporal differences in the supply of organic matter from the North Sea to the Wadden Sea.

Eutrophication remains a relevant issue in European legislation like the WFD or MSFD despite a nearly $50 \%$ reduction in nutrient loads. With decreasing anthropogenic eutrophication, natural variability of the North Sea primary production and biogeochemical cycling will become increasingly important in determining the organic matter dynamics in the Wadden Sea and it will become increasingly difficult to distinguish between anthropogenicinduced changes in phytoplankton dynamics and natural variability. McQuatters-Gollop et al. (2007) and McQuatters-Gollop and Vermaat (2011) showed that in North Sea coastal regions phytoplankton levels increased despite decreasing riverine nutrient loads. Their analysis is based on satellite data and continuous plankton recorder data and their conclusions contrast with the situation in the Wadden Sea where riverine nutrient loads have led to a decreased phytoplankton biomass and production (Cadée and Hegeman, 2002; van Beusekom et al., 2009b). But given the methods used by McQuatters-Gollop and co-workers, it is feasible, that the coastal stretch of the North Sea where riverine nutrients dominate the phytoplankton dynamics is quite narrow and that further offshore natural dynamics override the dynamics forced by riverine nutrient loads. Factors like timing of phytoplankton blooms (Cadée, 1986; Wiltshire et al., 2008; Tian et al., 2009), interannual dynamics in phytoplankton-zooplankton interaction (e.g. Colebrook, 1981, 1984, 1985; Edwards and Richardson, 2004) will influence the size and fate of the spring and early summer blooms in the North Sea and have an impact on the amount of organic matter settling to deeper water layers (van Beusekom and Diel-Christiansen, 2009) and transported towards the Wadden Sea.

The potential link between long-term changes in the North Sea and Wadden Sea ecology was demonstrated by Weijerman et al. (2005). They compiled 78 data sets (28 environmental data sets comprising atmospheric and oceanic variables and 50 biological time series representing a very wide range of marine organisms from phytoplankton to top-level predator). Based on a PCA analysis 
they found shifts around 1979 and 1988 and - albeit with lesser certainty - a shift around 1998. These shifts were clearest in the biological data but probably triggered by environmental conditions. Salinity and weather conditions played an important role in the 1979 shift, while in the 1988 shift, temperature and weather conditions were the predominant factors. These results show that large-scale forcing does influence both the Wadden Sea and the North Sea. The mechanism behind these large-scale shifts, however, is not unambiguously revealed by the applied statistics, but temperature probably played a key role (Hoegh-Guldberg and Bruno, 2010). Temperature was one of the key factors determining the long-term change in the northern Wadden Sea (Reise and van Beusekom, 2008; van Beusekom et al., 2010).

The analysis by Weijerman et al. (2005) suggests that large-scale effects like temperature or climate variation (NAO) impact the entire Wadden sea ecosystem. The study however does not resolve and distinguish different responses on a tidal basin scale. The largescale effects apparently did not interfere with the spatial eutrophication patterns suggesting that these patterns are quite robust against external forces. Whether that also holds for future change remains to be seen.

\subsection{Will the Wadden Sea respond in a uniform way to future change?}

\subsubsection{The impact of sea level rise}

Sea level rise is a slow process lagging behind atmospheric warming, and although there is an accelerating trend at the North Sea coast during recent years this is still in the range of observed long-term variability (Wahl et al., 2011). In the Wadden Sea, the balance between sea level rise and sediment supply from the North Sea to barrier islands and tidal basins has been a general precondition for its persistence over the past millennia (Flemming and Davis, 1994; Van Koningsveld et al., 2008). With an accelerating sea level rise, this balance is expected to become negative at first in the largest tidal basins and last in the smallest basins (CPSL, 2005; Van Goor et al., 2003). Small tidal basins have a larger share of intertidal flats as potential sedimentation areas than the large basins where the area share of the subtidal exceeds that of the intertidal zone. Under conditions of an ongoing acceleration in sea level rise, large tidal basins will turn into lagoons without tidal flats, while these may still persist in the smaller basins. Other factors like width of the tidal inlet as well as steepness of the slope towards the deeper parts of the North Sea may also affect the sediment import from the North Sea and thus the sediment budget of tidal basins (Hofstede, 1999; Pedersen and Bartholdy, 2006). Within basins, saltmarsh area, embankments and exchange across tidal divides are also important. The key process for the future of the Wadden Sea, still characterised by the largest tidal flats in the world, will be the sediment supply from the North Sea. Where and when this turns out to be deficient, management should be ready to decide whether or not to nourish tidal basins with sand taken from the North Sea (Reise, 2003; CPSL, 2010).

\subsubsection{Temperature increase: interacting effects with invasive species}

Greenhouse gases have significantly contributed to global temperature rise (IPCC, 2007). Europe has experienced extremely warm summers in the 2000s (Barriopedro et al., 2011), and in the Wadden Sea region recent years were characterised by milder winters followed by warmer summers (Fig. 6). The warm summer conditions represent the effects of the climate change over land affecting the shallow Wadden Sea, while the mild winters are mainly due to Multidecadal Atlantic Oscillations (AMO: Zhang et al., 2008; Häkkinen et al., 2011) representing the effect of the North Sea

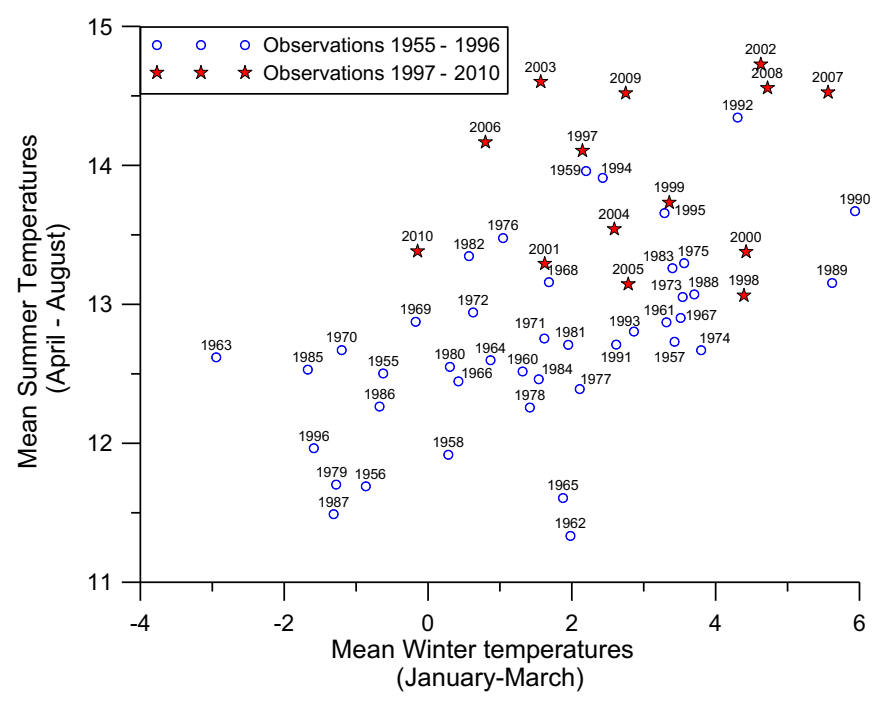

Fig. 6. A plot of mean summer air temperature in ${ }^{\circ} \mathrm{C}$ (April-August) vs. mean winter temperature (January-March) since 1955 at the weather station List on Sylt. Data were kindly provided by Deutscher Wetterdienst. After Witte et al. (2010) updated to 2010.

on the shallow coastal waters. This combination of mild winters and warm summers has facilitated populations of warm water species (i.e. Nehls et al., 2006; Witte et al., 2010) just as the occasional severe winters of previous years indirectly promoted bivalve recruitment during subsequent summers (Beukema and Dekker, 2005; Strasser et al., 2003). Reise and van Beusekom (2008) stressed the interactive effects of climate change and invasions of alien species. For instance temperature rise has caused an enhanced proliferation of introduced species (e.g. Diederich et al., 2005; Beukema and Dekker, 2011) some of which were already present in the Wadden Sea for decades (e.g. Loebl et al., 2006; Thieltges et al., 2004; Witte et al., 2010).

Recent investigations on the spatial and temporal occurrence of aliens reveal that non-native species are not evenly distributed throughout the Wadden Sea but show high spatiotemporal variability with concomitant effects on local diversity and species interactions (Kochmann et al., 2008; Markert et al., 2010; Buschbaum et al., this volume). However, the reasons for this are still open to speculation. Establishment of introduced species may be facilitated in large tidal basins due to better larval retention compared to small basins. In particular, the frequently introduced fouling species benefit from introduced hard substrates such as in ports and marinas and along armoured shorelines. Almost all aliens have not been directly introduced into the Wadden Sea but have secondarily entered this coastal region after having been introduced at major ports and aquaculture sites further south.

In the List tidal basin between the German island of Sylt and the Danish island of $R \emptyset \mathrm{m} \emptyset$, Pacific oysters have expanded their occurrence from the intertidal to the shallow subtidal where they provide anchorage for the Japanese seaweed Sargassum muticum, forming extensive kelp forests which constitute completely new habitat structures in the Wadden Sea. These are intensively used by a rich assemblage of resident species (Buschbaum et al., 2006; Polte and Buschbaum, 2008) but also provide a suitable habitat for further non-natives such as the skeleton shrimp Caprella mutica (Buschbaum and Reise, 2010). This Pacific species at first established on artificial structures such as harbour pontoons and buoys (Buschbaum and Gutow, 2005), and from there colonised the new kelp forest. This domino effect between Pacific oysters, the Japanese seaweed and the alien skeleton shrimp was only detected in the List tidal basin. It seems that besides the release of Pacific 
oysters from a local oyster farm, specific conditions in this area like the low eutrophication status (van Beusekom et al., 2009a) and good light condition (Loebl et al., 2009) - both directly related to the import of SPM and organic matter - have enabled this invasional meltdown (sensu Simberloff and Von Holle, 1999).

We extend the conclusions by Wolff et al. (2010) and Reise and van Beusekom (2008) that the main challenge for Wadden Sea science and management is to understand the interactive effects of sea level rise, temperature increase and the introduction of alien species and suggest that regional differences within the Wadden Sea need to be taken into account.

\section{Conclusions and implications for management}

Many of the threats identified 30 years ago to the Wadden Sea ecosystem like land claim, hunting, fishing, tourism or industrial pollution could be reduced or came to a halt by appropriate management (Wolff et al., 2010). Remaining future threats are sea level rise, global warming and the introduction of alien species. Despite a large reduction in riverine nutrient loads eutrophication remains an issue. The above factors all have in common that they have global or super-regional dimensions that cannot be managed by local authorities alone. Eutrophication has local aspects (local nutrient sources) but is largely driven by import from the North Sea where the effects of continental rivers become transformed and diluted by oceanic processes. In this respect, the Wadden Sea is more strongly linked to the ocean change than other coastal regions like in the semi-enclosed Baltic or Black Seas (e.g. McQuattersGollop et al., 2009).

Little attention has been given up to now to understand regional differences within the international Wadden Sea. This is a challenge to the Wadden Sea scientific community and requires a North Sea view on the Wadden Sea. This knowledge is prerequisite for a harmonised Wadden Sea management. Based on eutrophication data we propose a conceptual model linking North Sea hydrographic and biogeochemical processes to the (North Sea driven) transport of organic matter into the Wadden Sea and suggest that the shape of the recipient tidal basins and in particular the ratio between the distance between the tidal divides and the surface area determine the eutrophication status of tidal basins. Because of the importance of the North Sea ecosystem on the marginal Wadden Sea, the river basin concept as formulated by the Water Framework Directive (EC, 2000) is not applicable to the Wadden Sea. The import processes described above in combination with transboundary transport of nutrients (the importance of e.g. Rhinederived nutrients for nutrient budgets of the southeastern North Sea (Beddig et al., 1997)) suggest that North Sea-wide nutrient management is needed and that local reduction measures can only be successful if carried out in a wider European-wide context. The MSFD (EC, 2008) may contribute by defining a good ecological status (close to "undisturbed" conditions) of the coastal North Sea outside of the Wadden Sea. Nevertheless local aspects have to be taken into account because regional differences in the hydrodynamic conditions potentially lead to a different organic matter import and thus influence the ecological status of the Wadden Sea.

Regional differences can also be expected in response to sea level rise with smaller basins having a larger capacity to keep up the sediment balance during increased sea level rise, whereas larger basins may experience a loss of intertidal flats to become coastal lagoons. Estuaries and large tidal basins with armoured shorelines seem to be more susceptible to the establishment of introduced alien species than small tidal basins with more natural shorelines. Thus, conservation efforts to prevent non-native species introductions should not be limited to better detection and vector control but must also include habitat improvement. Briggs (2012) pointed out that a lack of top predators in coastal systems may additionally facilitate the establishment of alien species which often belong to lower trophic levels. He concluded that the ultimate goal of restoration should be the reintroduction of large-size, apex-level predators which became extinct in the Wadden Sea due to human exploitation (Lotze, 2005).

The aim of a "Good Environmental Status" in the Wadden Sea calls for an evaluation process which accounts for the given differences within the region and for an international management approach at the scale of the entire North Sea catchment area (reducing nutrient discharge), of the Northeast Atlantic coasts (prevention of alien species introductions) and at the global scale (reducing greenhouse gas emissions). At the local and regional scale, management should focus on adaptations to supra-regional and global change by re-introducing lost species, restoring habitat diversity along developed shorelines, considering sand nourishments to improve sediment balances in the face of sea level rise and by raising awareness for the need of adjusting life styles to thriving coastal ecosystems.

\section{Acknowledgement}

We are grateful for the constructive comments by two reviewers and Maria van Leeuwe. The research leading to these results has received funding from the European Community's Seventh Framework Programme (FP7/2007-2013) under grant agreement no. 226675 (KnowSeas) and from the WiMo project supported by Lower Saxony (Niedersächsische Ministerium für Umwelt und Klimaschutz, Niedersächsische Ministerium für Wissenschaft und Kultur).

\section{References}

Airoldi, L., Beck, M.W., 2007. Loss, status and trends for coastal marine habitats of Europe. Oceanogr. Mar. Biol. 45, 345-405.

Alldredge, A.L., Gotschalk, C.C., 1989. Direct observations on the mass flocculation of diatom blooms: characteristics, settling velocities and formation of diatom aggregates. Deep Sea Res. Pt I: Oceanogr. Res. Pap. 36, 159-171.

Andersen, T.J., Pejrup, M., Nielsen, A.A., 2006. Long-term and high-resolution measurements of bed level changes in a temperate, microtidal coastal lagoon. Mar. Geol. 226, 115-126.

Andersen, T.J., Lanuru, M., van Bernem, C., Pejrup, M., Riethmueller, R., 2010 Erodibility of a mixed mudflat dominated by microphytobenthos and Cerastoderma edule, East Frisian Wadden Sea, Germany. Estuar. Coast. Shelf Sci. 87, 197-206.

Bakker, J.F., Kellermann, A., Farke, H., Laursen, K., Knudsen, T., Marencic, H., 1998. Implementation of the Trilateral Monitoring and Assessment Program (TMAP). Common Wadden Sea Secretariat, Wilhelmshaven, Germany.

Barriopedro, D., Fischer, E.M., Luterbacher, J., Trigo, R.M., García-Herrera, R., 2011. The hot summer of 2010: redrawing the temperature record map of Europe. Sci. Total Environ. 332, 220-224.

Beddig, S., Brockmann, U., Dannecker, W., Körner, D., Pohlmann, T., Puls, W., 1997. Nitrogen fluxes in the German Bight. Mar. Pollut. Bull. 34, 382-394.

Beets, D.J., van der Spek, A.J.F., 2000. The Holocene evolution of the barrier and the back-barrier basins of Belgium and the Netherlands as a function of late Weichselian morphology, relative sea-level rise and sediment supply. Geol. Mijnb.-Neth. J. Geosci. 79, 3-16.

Beukema, J.J., Dekker, R., 2005. Decline of recruitment success in cockles and other bivalves in the Wadden Sea: possible role of climate change, predation on postlarvae and fisheries. Mar. Ecol. Prog. Ser. 287, 149-167.

Beukema, J.J., Dekker, R., 2011. Increasing species richness of the macrozoobenthic fauna on tidal flats of the Wadden Sea by local range expansion and invasion of exotic species. Helgol. Mar. Res. 65, 155-164.

Briggs, J.C., 2012. Marine species invasions in estuaries and harbours. Mar. Ecol. Prog. Ser. 449, 297-302.

Buhs, F., Reise, K., 1997. Epibenthic fauna dredged from tidal channels in the Wadden Sea of Schlewig-Holstein: spatial patterns and a long-term decline. Helgol. Meeresunters. 51, 343-359.

Burchard, H., Flöser, G., Staneva, J., Badewien, T.H., Riethmüller, R., 2008. Impact of density gradients on net sediment transport into the Wadden Sea. J. Phys Oceanogr. 38, 566-587.

Buschbaum, C., Gutow, L., 2005. Mass occurrence of an introduced crustacean (Caprella cf. mutica) in the south-eastern North Sea. Helgol. Mar. Res. 59, $252-253$. 
Buschbaum, C., Chapman, A.S., Saier, B., 2006. How an introduced seaweed can affect epibiota diversity in different coastal systems. Mar. Biol. 148, 743-754.

Buschbaum, C., Reise, K., 2010. Neues Leben im Weltnaturerbe Wattenmeer. Globalisierung unter Wasser. Biologie Unserer Zeit 40, 202-210.

Buschbaum, C., Lakschewitz, D., Reise, K., this volume. Non-native species invading the Wadden Sea ecosystem. Ocean Coast Manage.

Cadée, G.C., 1980. Reappraisal of the production and import of organic matter in the western Wadden Sea. Neth. J. Sea Res. 14, 305-322.

Cadée, G.C., 1986. Recurrent and changing seasonal patterns in phytoplankton of the westernmost inlet of the Dutch Wadden Sea from 1969 to 1985. Mar. Biol. 93 281-289.

Cadée, G.C., Hegeman, J., 2002. Phytoplankton in the Marsdiep at the end of the $20^{\text {th }}$ century; 30 years monitoring biomass, primary production, and Phaeocystis blooms. J. Sea Res. 48, 97-110.

Colebrook, J.M., 1981. Continuous plankton records: persistence in time-series of annual means of abundance of zooplankton. Mar. Biol. 61, 143-149.

Colebrook, J.M., 1984. Continuous plankton records: relationships between species of phytoplankton and zooplankton in the seasonal cycle. Mar. Biol. 83, 313-323.

Colebrook, J.M., 1985. Continuous plankton records: overwintering and annual fluctuations in the abundance of zooplankton. Mar. Biol. 84, 261-265.

CPSL, 2005. Coastal protection and sea level rise. Wadden Sea Ecosyst. 21, 1-47.

CPSL, 2010. Coastal protection and sea level rise. Wadden Sea Ecosyst. 28, 1-51.

CWSS, 1997. Stade Declaration and Wadden Sea Plan. Ministrial declaration of the Eight Trilateral Governmental Conference on the Protection of the Wadden Sea, October, 1997. Common Wadden Sea Secretariat, Wilhelmshaven, Germany.

CWSS, 2010. Wadden Sea Plan 2010. Eleventh Trilateral Governmental Conference on the Protection of the Wadden Sea. Common Wadden Sea Secretariat, Wilhelmshaven, Germany.

de Jonge, V.N., 2009. From a defensive to an integrated approach. In: Rijnhard, S. Folmer, H. (Eds.), Water Policy in the Netherlands. Resources of the Future, Washington, pp. 17-46.

de Jonge, V.N., Essink, K., Boddeke, R., 1993. The Dutch Wadden Sea - a changed ecosystem. Hydrobiologia 265, 45-71.

de Jonge, V.N., de Jong, D.J., van den Bergs, J., 1996. Reintroduction of eelgrass (Zostera marina) in the Dutch Wadden Sea; review of research and suggestions for management measures. J. Coast. Conserv. 2, 149-158.

Dellwig, O., Hinrichs, J., Hild, A., Brumsack, H.-J., 2000. Changing sedimentation in tidal flat sediments of the southern North Sea from the Holocene to the present: a geochemical approach. J. Sea Res. 44, 195-208.

den Hartog, C., Polderman, P., 1975. Changes in the seagrass populations of the Dutch Wadden Sea. Aquat. Bot. 1, 141-147.

Diederich, S., Nehls, G., van Beusekom, J.E.E., Reise, K., 2005. Introduced Pacific oysters (Crassostrea gigas) in the northern Wadden Sea: invasion accelerated by warm summers? Helgol. Mar. Res. 59, 97-106.

Doody, J.P., 2004. Coastal squeeze: a historical perspective. J. Coast. Conserv. 10, $129-138$.

Edwards, M., Richardson, A.J., 2004. Impact of climate change on marine pelagic phenology and trophic mismatch. Nature 430, 881-884.

Ehlers, J., Kunz, H., 1993. Morphology of the Wadden Sea: natural processes and human interferences. In: Proceedings of the 8th Symposium on Coastal and Ocean Management, pp. 65-84.

European Commission, 2000. Directive 2000/60/EC of the European Parliament and of the Council of 23 October 2000 establishing a framework for Community actions in the field of water policy. Off. J. Eur. Communities L327. 321.322.312.2000.

European Commission, 2008. Directive 2008/56/EC of the European Parliament and of the Council of 17 June 2008 establishing a framework for Community actions in the field of marine environmental policy (Marine Strategy Framework Directive). Off. J. Eur. Communities L164/119. 125.106.2008.

Flemming, B.W., Davis, R.A.J., 1994. Holocene evolution, morphodynamics and sedimentology of the Spiekeroog barrier island system (southern North Sea). Senckenb. Marit. 25, 117-155.

Flemming, B.W., Nyandwi, N., 1994. Land reclamation as a cause of fine-grained sediment depletion in backbarrier tidal flats (southern North Sea). Neth. J. Aquat. Ecol. 28, 299-307.

Giesen, W., van Katwijk, M.M., den Hartog, C., 1990a. Eelgrass condition and turbidity in the Dutch Wadden Sea. Aquat. Bot. 37, 71-85.

Giesen, W., van Katwijk, M.M., den Hartog, C., 1990b. Temperature, salinity, insolation and wasting disease of eelgrass (Zostera marina L) in the Dutch Wadden Sea in the 1930's. Neth. J. Sea Res. 25, 395-404.

Gieskes, W.W.C., van Bennekom, A.J., 1973. Unreliability of the ${ }^{14} \mathrm{C}$-method for estimating primary production in eutrophic Dutch coastal waters. Limnol. Oceanogr. 18, 494-495.

Grunwald, M., Dellwig, O., Kohlmeier, C., Kowalski, N., Beck, M., Badewien, T.H. Kotzur, S., Liebezeit, G., Brumsack, H.-J., 2010. Nutrient dynamics in a back barrier tidal basin of the Southern North Sea: time-series, model simulations, and budget estimates. J. Sea Res. 64, 199-212.

Hagmeier, A., Kändler, R., 1927. Neue Untersuchungen im nordfriesischen Wattenmeer und auf den fiskalischen Austernbänken. Wiss. Meeresunters. (Helgol.) 16, $1-99$.

Häkkinen, S., Rhines, P.B., Worthen, D.L., 2011. Atmospheric blocking and Atlatic multidecadal ocean variability. Science 334, 655-659.

Hoegh-Guldberg, O., Bruno, J.F., 2010. The impact of climate change on the world's marine ecosystems. Science 328, 1523-1528.

Hofstede, J.L.A., 1999. Regional differences in the morphologic behaviour of four German Wadden Sea barriers. Quatern. Int. 56, 99-106.
Hoselmann, C., Streif, H., 2004. Holocene sea-level rise and its effect on the mass balance of coastal deposits. Quatern. Int. 112, 89-103.

IPCC, 2007. Contribution of Working Group I to the Fourth Assessment Report of the Intergovernmental Panel on Climate Change, Summary for Policymakers, p. 18.

Joint, I., Pomroy, A., 1993. Phytoplankton biomass and production in the southern North Sea. Mar. Ecol. Prog. Ser. 99, 169-182.

Kastler, T., Michaelis, H., 1999. The decline of seagrasses, Zostera marina and Zostera noltii, in the Wadden Sea of Lower Saxony. Senckenb. Marit. 29, 77-80.

Kochmann, J., Buschbaum, C., ReiseVolkenborn, N., Reise, K., 2008. Shift from native mussels to alien oysters: differential effects of ecosystem engineers. J. Exp. Mar. Biol. 364, 1-10.

Kraan, C., Dekinga, A., Piersma, T., 2011. Now an empty mudflat: past and present benthic abundances in the western Dutch Wadden Sea. Helgol. Mar. Res. 65, $51-58$.

Lancelot, C., Billen, G., Sournia, A., Weisse, T., Colijn, F., Davies, M.J.W., Wassman, P., 1987. Phaeocystis blooms and nutrient enrichment in the continental coastal zones of the North Sea. Ambio 16, 38-46.

Loebl, M., Colijn, F., van Beusekom, J.E.E., Baretta-Bekker, J.G., Lancelot, C., Philippart, C.J.M., Rousseau, V., Wiltshire, K.H., 2009. Recent patterns in potential phytoplankton limitation along the Northwest European continental coast. J. Sea Res. 61, 34-43.

Loebl, M., van Beusekom, J.E.E., Reise, K., 2006. Spread of the neophyte Spartina anglica recently enhanced by increasing temperatures? Aquat. Ecol. 40, 315-324.

Lotze, H.K., 2005. Radical changes in the Wadden Sea fauna and flora over the last 2000 years. Helgol. Mar. Res. 59, 71-83.

Lotze, H.K., Reise, K., Worm, B., van Beusekom, J.E.E., Busch, M., Ehlers, A., Heinrich, D., Hoffmann, R.C., Holm, P., Jensen, C., Knottnerus, O.S., Langjanki, N. Prummel, W., Vollmer, M., Wolff, W.J., 2005. Human transformation of the Wadden Sea ecosystem through time: a synthesis. Helgol. Mar. Res. 59, 84-95.

Marencic, H., de Vlas, J., 2009. Quality Status Report 2009, Wadden Sea Ecosystem. No. 25. Common Wadden Sea Secretariat, Trilateral Monitoring and Assessment Group, Wilhelmshaven, Germany.

Markert, A., Wehrmann, A., Kröncke, I., 2010. Recently established Crassostrea-reefs versus native Mytilus-beds: differences in ecosystem engineering affects the macrofaunal communities (Wadden Sea of Lower Saxony, southern German Bight). Biol. Invasions 12, 15-32.

McQuatters-Gollop, A., Raitsos, D.E., Edwards, M., Pradhan, Y., Mee, L.D., Lavender, S.J., Attrill, M.J., 2007. A long-term chlorophyll data set reveals regime shift in North Sea phytoplankton biomass unconnected to nutrient trends. Limnol. Oceanogr. 52, 635-648.

McQuatters-Gollop, A., Gilbert, A.J., Mee, L.D., Vermaat, J.E., Artioli, Y., Humborg, C. Wulff, F., 2009. How well do ecosystem indicators communicate the effects of anthropogenic eutrophication? Estuar. Coast. Shelf Sci. 82, 583-596.

McQuatters-Gollop, A., Vermaat, J.E., 2011. Covariance among North Sea ecosystem state indicators during the past 50 years - contrasts between coastal and open waters. J. Sea Res. 65, 284-292.

Möbius, K., 1877. Die Austern und die Austernwirthschaft. Hempel \& Parey, Berlin.

Möbius, K., 1893. Über die Tiere der schleswig-holsteinischen Austernbänke, ihre physikalischen und biologischen Lebensverhältnisse. Sber. Preuss. Akad. Wiss. 7, 33-58.

Nehls, G., Diederich, S., Thieltges, D.W., Strasser, M., 2006. Wadden Sea mussel beds invaded by oysters and slipper limpets: competition or climate control? Helgol. Mar. Res. 60, 135-143.

Nienburg, W., 1927. Zur Ökologie der Flora des Wattenmeeres. I. Der Königshafen by List auf Sylt. Wiss. Meeresunters. (Kiel) 20, 146-196.

Oost, A.P., de Boer, P.L., 1994. Sedimentology and development of barrier islands, ebb-tidal deltas, inlets and backbarrier areas of the Dutch Wadden Sea. Senckenb. Marit. 24, 65-115.

Otto, L., Zimmerman, J., Furnes, G., Mork, M., Saetre, R., Becker, G., 1990. Review of the physical oceanography of the North Sea. Neth. J. Sea Res. 26, 161-238.

Pedersen, J.B.T., Bartholdy, J., 2006. Budgets for fine-grained sediment in the Danish Wadden Sea. Mar. Geol. 235, 101-117.

Philippart, C.J.M., 1995. Effect of periphyton grazing by Hydrobia ulvae on the growth of Zostera noltii on a tidal flat in the Dutch Wadden Sea. Mar. Biol. 122, 431-437.

Philippart, C.J.M., Beukema, J.J., Cadée, G.C., Dekker, R., Goedhart, P.W., Iperen, J.M.v., Leopold, M.F., Herman, P.M.J., 2007. Impact of nutrients on coastal communities. Ecosystems 10, 95-118.

Polte, P., Buschbaum, C., 2008. Native pipefish (Entelurus Aequareus) promoted by the introduced seaweed Sargassum muticum in the northern Wadden Sea. Aquat. Biol. 3, 11-18.

Postma, H., 1954. Hydrography of the Dutch Wadden Sea. Arch. Néerl. Zool. 10, 405-511.

Postma, H., 1981. Exchange of materials between the North Sea and the Wadden Sea. Mar. Geol. 40, 199-215.

Postma, H., 1984. Introduction to the symposium on organic matter in the Wadden Sea. Neth. Inst. Sea Res. Publ. Ser. 10, 15-22.

Reid, P.C., Lancelot, C., Gieskes, W.W.C., Hagmeier, E., Weichart, G., 1990. Phytoplankton of the North Sea and its dynamics: a review. Neth. J. Sea Res. 26, 295-331.

Reise, K., 2003. More sand to the shorelines of the Wadden Sea. Harmonizing coastal defense with habitat dynamics. In: Wefer, G., Mantoura, F. (Eds.), Marine Science Frontiers for Europe. Springer-Verlag, Berlin, Heidelberg, New York, Tokyo, pp. 203-216.

Reise, K., 2005. Coast of change: habitat loss and transformations in the Wadden Sea. Helgol. Mar. Res. 59, 9-21. 
Reise, K., Buhs, F., 1999. Reply to the comment of Damm and Neudecker (1999): long-term decline in epibenthic fauna of tidal channels near the island of Sylt in the northern Wadden Sea. Helgol. Mar. Res. 53, 143-145.

Reise, K., van Beusekom, J.E.E., 2008. Interactive effects of global and regional change on a coastal ecosystem. Helgol. Mar. Res. 62, 85-91.

Reise, K., Herre, E., Sturm, M., 2008. Mudflat biota since the 1930's: change beyond return? Helgol. Mar. Res. 62, 13-22.

Reise, K., Baptist, M., Burbridge, P., Dankers, N.M.J.A., Fischer, L., Flemming, B.W., Oost, A.P., Smit, C., 2010. The Wadden Sea - a universally outstanding tidal wetland. Wadden Sea Ecosyst. 29, 7-24.

Rullkötter, J., 2009. The back-barrier tidal flats in the southern North Sea a multidisciplinary approach to reveal the main driving forces shaping the system. Ocean Dyn. 59, 157-165.

Simberloff, D., Von Holle, B., 1999. Positive interactions of nonindigenous species: invasional meltdown? Biol. Invasions 1, 21-32.

Staats, N., de Deckere, E., Kornman, B., van der Lee, W., Termaat, R., Terwindt, J., de Winder, B., 2001. Observations on suspended matter (SPM) and microalgae in the Dollard Estuary, The Netherlands: importance of late winter ice cover of the intertidal flats. Estuar. Coast. Shelf Sci. 53, 297-306.

Staneva, J., Stanev, E.V., Wolf, J.-O., Badewein, T., Reuter, R., Flemming, B. 2009. Hydrodynamics and sediment dynamics in the German Bight. A focus on observations and numerical modelling in the East Frisian Wadden Sea. Cont. Shelf Res. 29, 302-319.

Strasser, M., Dekker, R., Essink, K., Gunther, C.P., Jaklin, S., Kröncke, I., Madsen, P.B. Michaelis, H., Vedel, G., 2003. How predictable is high bivalve recruitment in the Wadden Sea after a severe winter? J. Sea Res. 49, 47-57.

Thieltges, D.W., Strasser, M., van Beusekom, J.E.E., Reise, K., 2004. Too cold to prosper - winter mortality prevents population increase of the introduced American slipper limpet Crepidula fornicata in northern Europe. J. Exp. Mar. Biol. Ecol. 311, 375-391.

Tian, T., Merico, A., Su, J., Staneva, J., Wiltshire, K., Wirtz, K., 2009. Importance of resuspended sediment dynamics for the phytoplankton spring bloom in a coastal marine ecosystem. J. Sea Res. 62, 214-228.

van Bennekom, A.J., Wetsteijn, F.J., 1990. The winter distribution of nutrients in the southern bight of the North Sea (1961-1978) and in the estuaries of the Scheldt and the Rhine/Meuse. Neth. J. Sea Res. 25, 75-87.

Van Beusekom, J.E.E., Brockmann, U.H., 1998. Transformation of phosphorus in the Elbe estuary. Estuaries 21, 518-526.

van Beusekom, J.E.E., Brockmann, U.H., Hesse, K.J., Hickel, W., Poremba, K., Tillmann, U., 1999. The importance of sediments in the transformation and turnover of nutrients and organic matter in the Wadden Sea and German Bight. Germ. J. Hydrogr. 51, 245-266.

van Beusekom, J.E.E., de Jonge, V.N., 2002. Long-term changes in Wadden Sea nutrient cycles: importance of organic matter import from the North Sea. Hydrobiologia 475/476, 185-194.

van Beusekom, J.E.E., Reise, K., 2008. Editorial: long-term ecological change in the northern Wadden Sea. Helgol. Mar. Res. 62, 1-2.

van Beusekom, J.E.E., Diel-Christiansen, S., 2009. Global change and the biogeochemistry of the North Sea: the possible role of phytoplankton and phytoplankton grazing. Int. J. Earth Sci. 98, 269-280.

van Beusekom, J.E.E., Bot, P., Carstensen, J., Goebel, J., Lenhart, H., Pätsch, J. Petenati, T., Raabe, T., Reise, K., Wetsteijn, B., 2009a. Eutrophication. Thematic Report No. 6. In: Marencic, H., de Vlas, J. (Eds.), Quality Status Report 2009, Wadden Sea Ecosystem. No 25. Common Wadden Sea
Secretariat, Trilateral Monitoring and Assessment Group, Wilhelmshaven, Germany.

van Beusekom, J.E.E., Loebl, M., Martens, P., 2009b. Distant riverine nutrient supply and local temperature drive the long-term phytoplankton development in a temperate coastal basin. J. Sea Res. 61, 26-33.

van Beusekom, J.E.E., Buschbaum, C., Loebl, M., Martens, P., Reise, K., 2010. Long term ecological change in the northern Wadden Sea. In: Müller, F., Baessler, C. Schubert, H., Klotz, S. (Eds.), Long-Term Ecological Research: Between Theory and Application. Springer, Heidelberg.

van Beusekom, J.E.E., de Jonge, V.N., 2012. Dissolved organic phosphorus: an indicator of organic matter turnover? Estuar. Coast. Shelf Sci.. doi:10.1016/ j.ecss.2011.12.004

Van Goor, M.A., Zitman, T.J., Wang, Z.B., Stive, M.J.F., 2003. Impact of sea-level rise on the equilibrium state of tidal inlets. Mar. Geol. 202, 211-227.

van Katwijk, M.M., Vergeer, L.T.H., Schmitz, G.H.W., Roelofs, J.G.M., 1997. Ammonium toxicity in eelgrass Zostera marina. Mar. Ecol. Prog. Ser. 157, 159-173.

van Katwijk, M.M., Schmitz, G.H.W., Gasseling, A.P., van Avesaath, P.H., 1999. Effects of salinity and nutrient load and their interaction on Zostera marina. Mar. Ecol Prog. Ser. 190, 155-165.

Van Koningsveld, M., Mulder, J.P.M., Stive, M.J.F., Van der Valk, L., Van der Weck, A.W., 2008. Living with sea-level rise and climate change: a case study of the Netherlands. J. Coast. Res. 24, 367-379.

van Straaten, L.M.J.U., Kuenen, P.H., 1957. Accumulation of fine-grained sediments in the Dutch Wadden Sea. Geol. Mijnb. 19, 319-354.

Verwey, J., 1952. On the ecology of cockle and mussel in the Dutch Wadden Sea. Arch. Néerl. Zool. 10, 171-239.

Wahl, T., Jensen, J., Frank, T., Haigh, I.D., 2011. Improved estimates of mean sea level changes in the German Bight over the last 166 years. Ocean Dyn. 61 701-715.

Weijerman, M., Lindeboom, H.J., Zuur, A., 2005. Regime shifts in marine ecosystems of the North Sea and Wadden Sea. Mar. Ecol. Prog. Ser. 289, 21-39.

Wiersma, A.P., Oost, A.P., van der Berg, M.W., Vos, P.C., Marges, V., de Vries, S., 2009 Geomorphology. Thematic Report No. 9. In: Marencic, H., de Vlas, J. (Eds.), Quality Status Report 2009, Wadden Sea Ecosystem. No. 25. Common Wadden Sea Secretariat, Trilateral Monitoring and Assessment Group, Wilhelmshaven, Germany.

Wiltshire, K.H., Malzahn, A.M., Wirtz, K., Greve, W., Janisch, S., Mangelsdorf, P., Manly, B.F.J., Boersma, M., 2008. Resilience of North Sea phytoplankton spring bloom dynamics: an analysis of long-term data at Helgoland Roads. Limnol. Oceanogr. 53, 1294-1302.

Witte, S., Buschbaum, C., van Beusekom, J.E.E., Reise, K., 2010. Does climatic warming explain why an introduced barnacle finally takes over after a lag of more than 50 years? Biol. Invasions 12, 3579-3589.

Wohlenberg, E., 1935. Beobachtungen über das Seegras Zostera marina L. und seine Erkrankung im nordfriesischen Wattenmeer. Nordelbingen 11,1-19.

Wohlenberg, E., 1937. Die Wattenmeer-Lebensgemeinschaften im Königshafen von Sylt. Helgol. Wiss. Meeresunters. 1, 1-92.

Wolff, W.J., Binsbergen, M., 1985. Het beheer van de Wadden. De visie van de Werkgroep Waddengebied. Stichting Veth tot Steun aan Waddenonderzoek, Arnhem, 64 pp.

Wolff, W.J., Bakker, J.P., Laursen, K., Reise, K., 2010. Wadden Sea quality status report - synthesis report 2010. Wadden Sea Ecosyst. 29, 27-74.

Zhang, X., Sorteberg, A., Zhang, J., Gerdes, R., Comiso, J.C., 2008. Recent radical shifts of atmospheric circulations and rapid changes in Arctic climate system. Geophys. Res. Lett. 35, L22701. 